\title{
Design Innovation of Café During Pandemic (Case Study: Olifant Café)
}

\author{
Ema Hidayati, Edward Endrianto Pandelaki, and Bangun I. R. Harsritanto* \\ Department of Architecture, Universitas Diponegoro, Jl. Prof. Soedarto, Tembalang, Semarang 50275
}

\begin{abstract}
Open in early 2020 as the pandemic rushed into Indonesia, made culinary and hospitality industry such: café must adopt a new normal quickly. New normal regulation from the authorities made restriction in crowd maker activities and regional mobility (PSBB). On this situation, Café shall make innovation to survive from the further economic crisis. Some protocol such as: wash both hands with soap, body temperature check before entering the buildings; limitation in number of visitors must be performed. This study purpose is to investigate the design innovation of café business during this pandemic. Using direct physical observation and literature studies, this research obtains results of certain innovation by the cafe such as: redesigning the interior layout, emphasizing the room ambience, and photo spots addition. Those innovations were expected to maintain café business during pandemic.
\end{abstract}

\section{Introduction}

The coronavirus from Wuhan, China, has penetrated Southeast Asia, including Indonesia, in 2019 until now $[1,2]$. This virus has spread all over the earth, so it can be said to be pandemic $[3,4,5]$. The spread of this virus is via physical contact, droplets and airborne. The covid 19 symptoms can be seen on hard breath, cough, flu, loss of smell and fever [6]. The total covid19 cases in Indonesia reached 1.74 million cases with detail of 1.61 million were cured, and 48,305 were passed away. In 2021, January has reached 14,518 new cases, which is the highest case in Indonesia [7].

To minimize the spread of this virus, the Indonesian government campaigned for the New Normal Adaptation (AKB). The AKB is a new habit to maintain health and avoid the spread of the Covid-19 virus by implementing health protocols $(5 \mathrm{M})$ such as washing hands, using masks, keeping physical distance, avoiding crowd, and minimizing mobility. By following health protocol and new normal adaptation, people can avoid the Covid-19 virus and continue their activities without harming others [8].

The spread of the virus can occur in crowded places in public buildings such as malls, cafes, religious buildings, cinemas, etc. [9]. Therefore, this situation brought a significant impact on the economic sector, especially: culinary business. Many restaurants were bankrupted due to the decreased number of consumers at this time [10].

* Corresponding author: bangunirh@arsitektur.undip.ac.id 
Regional policy of restriction in activities and mobility (PSBB) by the government to minimize the spread of Covid-19 making a significant decrease in café visitors. So, many cafés are reducing their price, products, and employees. Entrepreneurs in the culinary business are trying hard to keep their business from more losses [11]

Previous research of café during a pandemic $[8,12,13]$ has shown some innovations, such as photo spots additions, new menu, and enhancement of the marketing section to attract more visitors. They didn't inform the innovation in physical and service design yet. So, the purpose of this research is to investigate the innovation of café business during this pandemic on design and service innovations regarding health protocols.

\section{Method}

This study uses a literature study and direct site observation. The data is obtained from the site and descriptively analysed with the health protocol, interior design and café related literature (Figure. 1). The data such as location, photo, and layout being collected by several visits during pandemic on 2021.

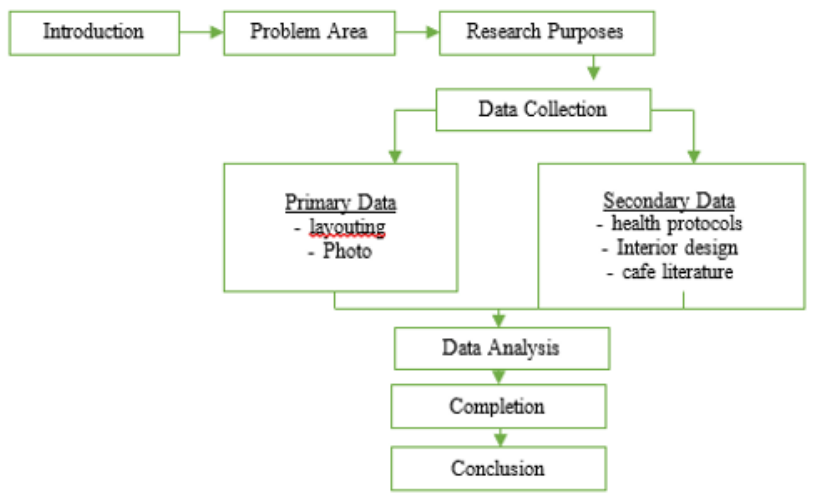

Fig. 1. Research diagram.

\section{Material and Discussion}

This café is located on West Pleburan Street No. 16, Pleburan, Semarang City. (See Figure. 2). This café opens from 07.00 - 23.00 WIB. It has two floors with indoor and outdoor dining facilities. The research being investigated both floors and reported the physical evidence only.

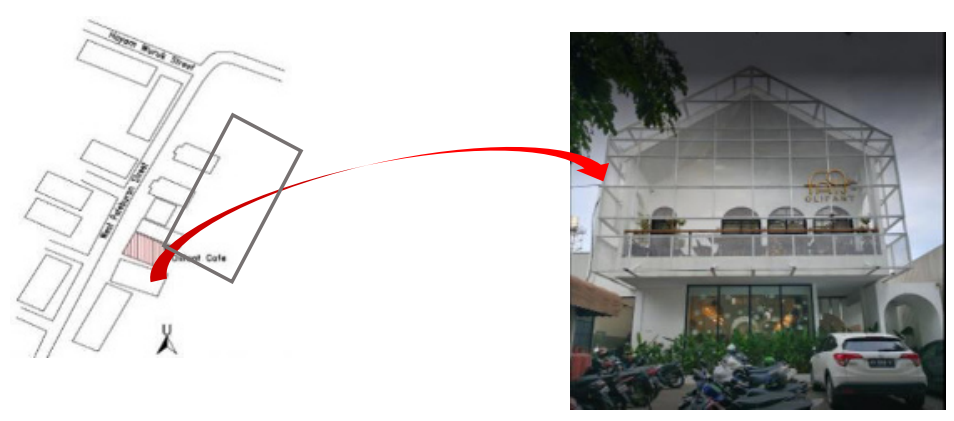

Fig.2. Site Olifant Café. 


\subsection{Café Design Innovation during Pandemic}

\subsubsection{Circulation Scenario}

The circulation of visitors is shown in the red arrow (Figure. 3). The visitors come from the lobby after checking the temperature, choose a table then order menus using a barcode scan on the table. This cafe uses "on table service" that made visitors order and served by waiters at their tables. To minimize the physical touch and keep the physical distancing of waiters and visitors, the waiter presents the menu to the dining table complete with cutlery by the operating procedure shown in Figure. 4. This scenario also keeps the visitor from roaming to other places, except to dine at a table, go to the toilet or pay the bill at cashier.
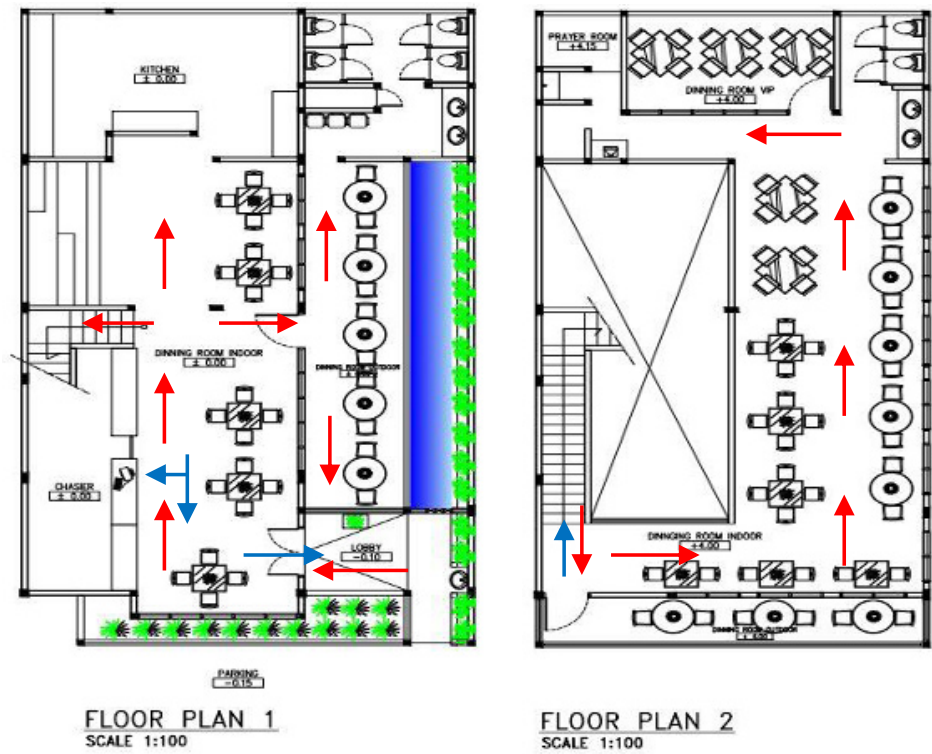

FLOOR PLAN 2
SCALE $1: 100$

Fig. 3. Floor Plan Olifant Café.

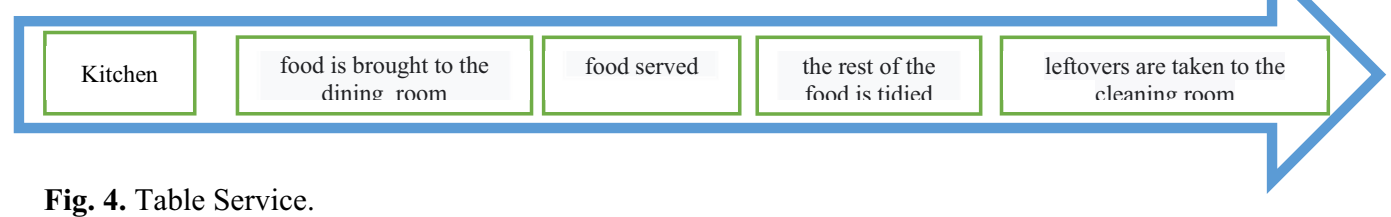

Fig. 4. Table Service.

\subsubsection{Temperature Check \& Washing Faucet on Lobby}

The olifant lobby is located at the entrance to the café. At this area, a temperature check was performed. This temperature check is a mandatory procedure written by the minister of health regulation [14] and related research body temperature with COVID 19 [15]. So, if the visitor has a fever or more than $37^{\prime} \mathrm{C}$ of body temperature, the café could not allow them to enter. Furthermore, the café administrator may contact the COVID 19 task force to check the visitors. This lobby is also equipped with a sink so that visitors wash their hands before entering the café area. To make a friendlier ambience, this lobby was decorated with the theme of the café decoration, adjusting the situation and conditions. This month coincides 
with the month of Ramadan so that the decoration of the café nuanced Ramadan. Placement of lighting on unique spots that add a more dramatic impression. (Figure. 5). This atmosphere become mandatory for café to maintain the space ambience [16].
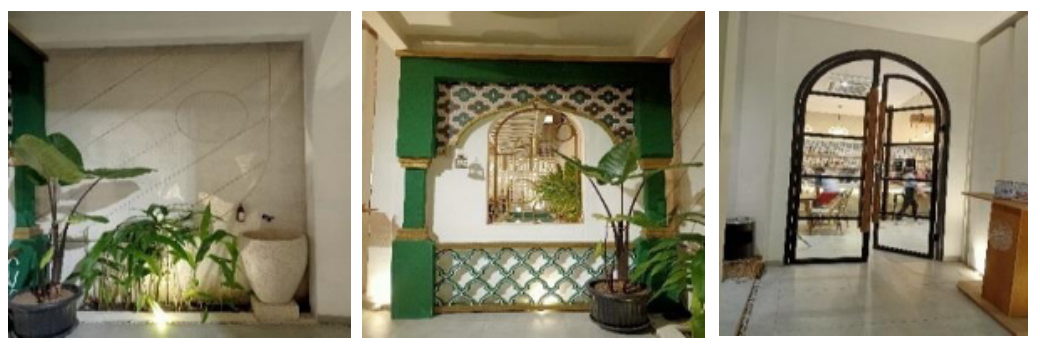

Fig. 5. Lobby Olifant Café.

\subsubsection{Physical Distance Layout}

To provide physical distancing on the table and seats, cafe Olifant applies the strategy of a table for four-seaters being reduced into two people only by giving an (X) mark on the chair. By giving the mark, the visitors shall understand and follow the scenario (Figure. 6). The distance between the tables is also assured, with at least 2 meters to meet the health protocol regulations. The cafe workers are also being ordered to keep the scenario of health protocol being followed by the visitors.

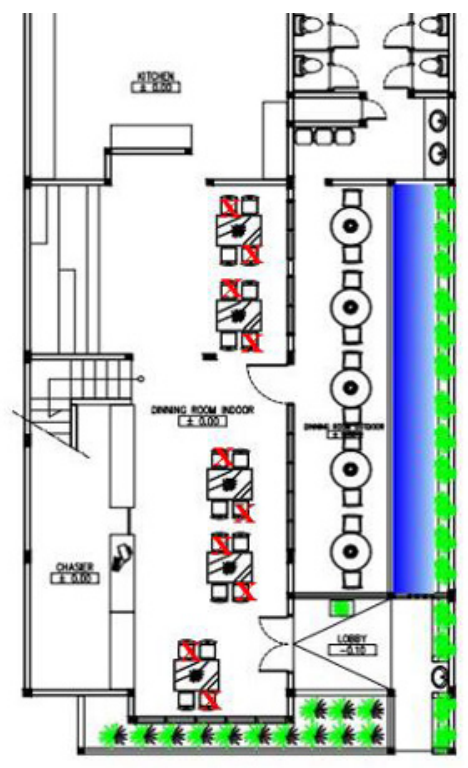

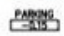

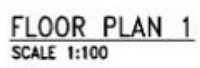

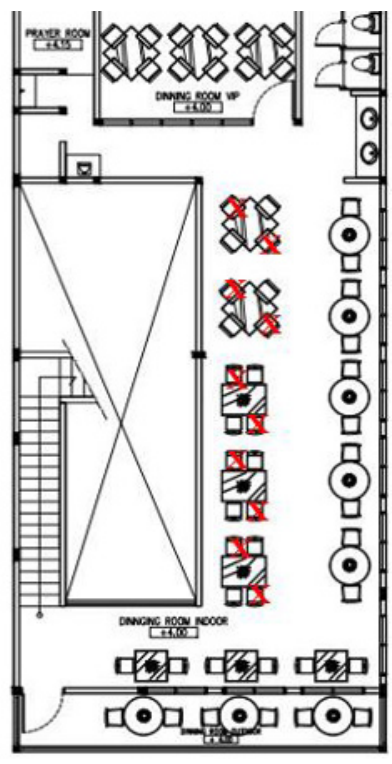

FLOOR PLAN 2 SCALE 1:100

Fig. 6. Dining table layout. 


\subsubsection{Attractive Interior Design}

Photo spots have been prepared to attract visitors to the café [8]. This spot is decorated according to the existing situation and conditions, such: Christmas, Ramadan, etc. This photo spot is being a unique attraction for visitors. This themed photo spot creates a new atmosphere from another café [16]. Because at this time, visitors like to take selfies. In addition, this photo spot indirectly carries out promotional branding to others if the photo is uploaded to social media [17]. (Figure.7)
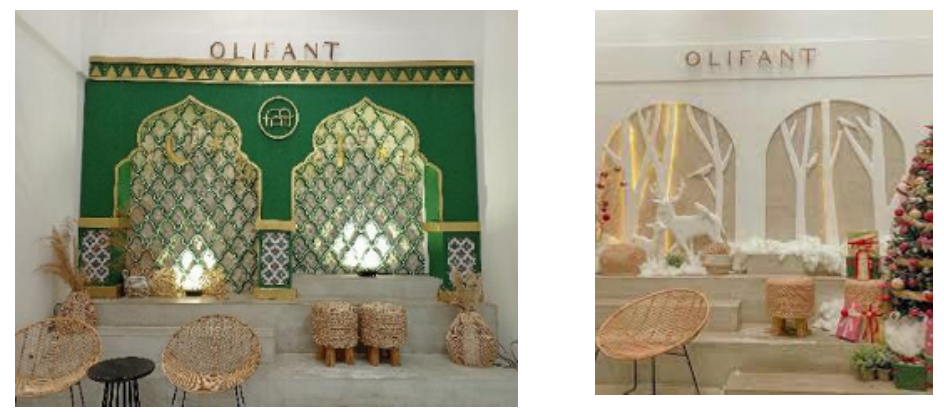

Fig.7. Photo Spot Decoration (left: ramadan, right: christmas).

The stairs as the access to the 2nd floor was being decorated with bohemian style such: combination of white colour on the wall, brown colour on the wall decoration and floor colour make a simple elegant impression. (Figure. 8).
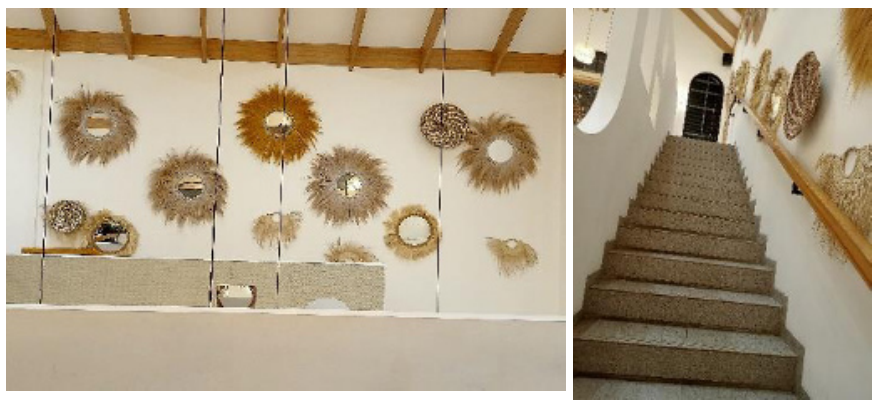

Fig. 8. The Stairs.

The all-white appearance and air vent brick on bathroom were being applied to add aesthetic. The plantation of green vegetation was made the impression of cool and clean. Therefore, this café is having all corners to please the visitor for taking pictures. (Figure. 9)
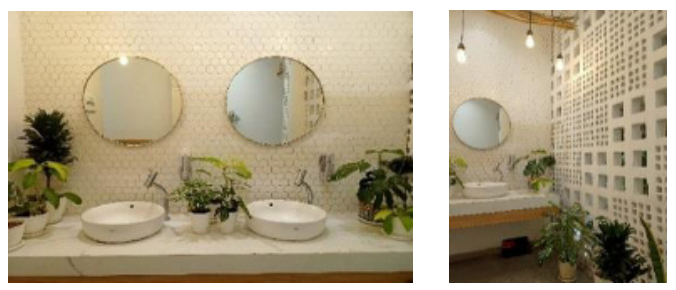

Fig. 9. Photo Spot in The Bathroom. 


\subsection{Cafe Service Innovation during Pandemic}

\subsubsection{Barcode on Table}

The usage of barcode menus on the table has become an innovation in health protocols during a pandemic for minimizing touch. Previously the used book menus offered by waiters but now with a barcode menu on the table, visitors can scan a barcode using their phone to see the menu and then call the waiter for the menu to be ordered. (Figure. 10)

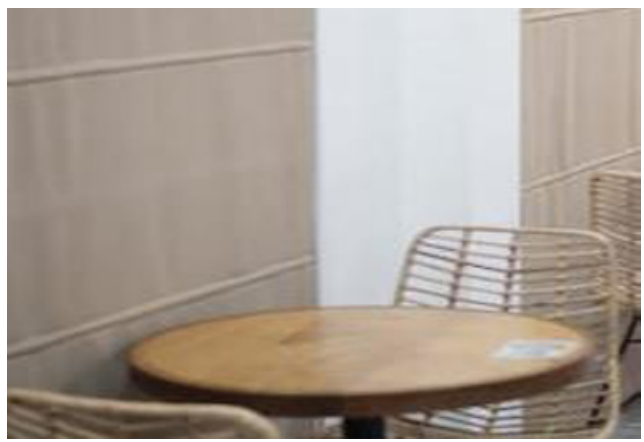

Fig. 10. Barcode on Table.

\subsubsection{Multiple Payment Option}

The bill of this cafe can be pay cash by real money or electronic money by scan the GPN barcode on the cashier area. The implementation of GPN barcode scan, makes easier payments, not making long queue and reduce physical contact between cashier and visitors. Near the cashier counter also being facilitated with a hand sanitizer to be used after doing cash payments transaction.

\section{Conclusion}

Innovation is a response to many limitations and conditions. In a Pandemic situation, Café as a culinary business must make some improvements in physical and service. Regarding the health protocols, ministry of health regulation, market demands and technology, some innovation, such: circulation scenario, temperature check and water faucet on the lobby, physical distancing layout, attraction interior design, barcode menu on the table, multiple payment options have been implemented. With designed scenarios in visitor circulation, the café can apply body temperature checks and handwashing in the lobby and prepare the table for physical distancing regulation. The photo spots placement, thematic decorations, and clean hygienist image have been installed to attract more visitors. Finally, technology innovation has been applied in minimizing personal contact during the order, service and pay. Thus, this Olifant café design innovation is an effort to maintain the culinary business during a pandemic. The strategy of Olifant café can be adapted not only in culinary sectors but also in other public buildings for keeping their activities and business on the healthy and safe track.

This research was financially supported by The Faculty of Engineering, Diponegoro University, Indonesia through Strategic Research Grant 2021. 


\section{References}

[1] Y.-R. Guo, Q.-D. Cao, Z.-S. Hong, Y.-Y. Tan, S.-D. Chen, H.-J. Jin, K.-S. Tan, D.-Y. Wang, Y. Yan, The Origin, Transmission and Clinical Therapies on Coronavirus Disease 2019 (COVID-19) Outbreak - An Update on the Status, Military Medical Research, 7(11), (2020)

[2] D. Cucinotta, M. Vanelli, WHO declares COVID-19 a pandemic, Acta Bio-Medica: Atenei Parmensis, 91(1), 157-160 (2020)

[3] S. S. Hare, A. Nair, Covid-19 pandemic: Summary of current and emerging issues for radiographers, Impact News Service, (2020)

[4] M. K. Aga, N. Kumar, J. Aarthi, G. Mawari, S. Garg, I. Rohatgi, From SARS-CoV to Coronavirus Disease 2019 (COVID-19)-A Brief Review, Journal of Advanced Research in Medicine, 6(4), 1-9 (2019)

[5] A. Spinelli, G. Pellino, COVID-19 pandemic: perspectives on an unfolding crisis, The British Journal of Surgery, 107(7), 785-787 (2020)

[6] A. Rohmah, Pandemi Covid-19 dan Dampaknya Terhadap Perilaku Konsumen di Indonesia, Jurnal Inovasi Penelitian, 1373-1378 (2020)

[7] CSSEGISandData, (May, 2021), JHU CSSE COVID-19 Dataset, Retrieved from https://github.com/CSSEGISandData/COVID-19/tree/master/csse_covid_19_data.

[8] D. S. Amelia, L. Suwarni, Selviana, Mawardi, Kesiapan Rumah Makan di Era New Normal Studi Cross Sectional Rumah Makan di Kota Pontianak, Jurnal Ilmu Kesehatan Masyarakat, 9(4), 216-221 (2020)

[9] B. I. Harsritanto, S. Nugroho, F. Dewanta, Undesignated Academic Mosque Response Toward COVID--19 Pandemic, in E3S Web Conf., 202, 07056 (2020)

[10] Taufik, E. A. Ayuningtyas, Dampak Pandemi Covid-19 Terhadap Bisnis dan Eksistensi Platfrom Online, Jurnal Pengembangan Wiraswasta, 21-32 (2020)

[11] F. A. Prakoso, Dampak Coronavirus Disease (Covid-19) Terhadap Industri Food \& Beverages, Jurnal Manajemen Bisnis, 1-6 (2020)

[12] R. Ambar, W. P. Sari, Komunikasi Pemasaran UMKM dalam Beradaptasi di Masa Pandemi Covid-19 (Studi Kasus Hello Cafe), Prologia, 5(1), 167-174 (2021)

[13] P. Natalie, A. P. Redaputri, Analysis of Cafe Wanowan Bandar Lampung Business Strategy Decision Making in the Middle of Covid-19 Pandemic, International Journal of Research and Review, 8(3), 562-569 (2021)

[14] Kementrian Kesehatan Republik Indonesia, Protokol kesehatan bagi masyarakat di tempat dan fasilitas umum dalam rangka pencegahan dan pengendalian corona virus disease 2019 (COVID-19), (2020)

[15] S. Tharakan, K. Nomoto, K. Ishikawa, Body temperature correlates with mortality in COVID-19 patients, Critical Care, 24(298), 1364-8535 (2020)

[16] A. F. Handiani, A. S. Cynantya, B. I. R. Harsritanto, How Student's Cafe at Tembalang Built Their Atmospheres, CISAK 2019, 122-129 (2019) 
[17] O. Trinanda, A. Y. Sari, Selfie tourism dan electronic word of mouth sebagai antesden re-visit intention, Benefita, 4(3), 526-535 (2019) 